\title{
El exilio en clave latinoamericana (II)
}

En el número anterior de Estudios sosteníamos que el exilio fue un territorio lábil en el que habitaron desde la orgullosa aceptación de la derrota, la mirada autocrítica y el empeño tenaz en mantener en alto la vocación emancipatoria, hasta el angustioso espacio en el que se difuminaron los sueños, hundidos en el fango de la melancolía. También fue un espacio marcado por la heterogeneidad. Así, la evocación del exilio argentino en Madrid permite también recordar el duelo entre el COSPA (Comité de Solidaridad con el Pueblo Argentino) y su entorno más amplio (la Casa Argentina), ambos vinculados a Montoneros y el PRT (Partido Revolucionario de los Trabajadores) por un lado y, por otro, el marxista - pero autocrítico de la experiencia de la lucha armada- CALPA (Comité de Ayuda a la Lucha del Pueblo Argentino) y su periferia más extendida (el Centro Argentino), liderados por los abogados Gustavo Roca (hijo de Deodoro Roca, referente intelectual de la Reforma Universitaria de Córdoba en 1918), Eduardo Luis Duhalde (inspirador de la revista Militancia y, años más tarde, secretario de Derechos Humanos del gobierno nacional entre 2003 y 2015) y el memorable periodista Alipio «Tito» Paoletti.

El signo plural del exilio se refleja -en este segundo número dedicado al tema- en las revistas forjadas a su sombra, en sus memorias y en sus narrativas literarias. La revista Resumen, editada en Madrid, vinculada al exilio peronista, la publicación Testimonio Latinoamericano, surgida en el ámbito de Cataluña, que tuvo entre sus inspiradores a los intelectuales Hugo Chumbita y Álvaro Abós; del exilio chileno la revista ChileAmérica, expresión de sectores vinculados al Partido Demócrata Cristiano (PDC) y la Izquierda Cristiana (IC); en el caso de los españoles en México se rescata la producción de la revista Futuro, que a diferencia de las anteriores no fue presidida por un exiliado sino por un dirigente obrero del país de recepción: el comunista mexicano Lombardo Toledano. Sus páginas son analizadas a la luz de las categorías teóricas de Bourdieu, Bajtín y Sarlo e incluye una interpretación del frente poético solidario a través de las poesías de guerra. El tema de los hijos del exilio tratado de un modo novedoso y un análisis de la experiencia traumática del largo exilio dominicano a través de las memorias de César Romero, cierran las contribuciones presentes en este volumen. 
Si bien los aportes contenidos en este número cubren un vacío, muchas revistas del exilio quedan fuera de esta recopilación, como DEBATE, dirigida por Miguel Ángel García y publicada en Roma, Italia. Era distribuida vía aérea en México, Panamá, Perú, Venezuela, los Estados Unidos, Holanda, Suecia, los países del sur de Europa e Israel. El reto pendiente supone hacer del estudio de esas publicaciones que son políticas y culturales a la vez, un programa sostenido de investigación.

Como es de rigor, este número incluye también una sección de comentarios bibliográficos. Sus autoras, provenientes de las universidades nacionales de Mar del Plata y del Nordeste, analizan dos obras, una sobre experiencias juveniles durante la última dictadura en Rosario (197683) y otra sobre las claves de la historia contemporánea de Córdoba.

César Tcach Director de Estudios 